social problems of workers and employees of complex industries headed by them, willingness to finance socially significant projects, thinking in both state and high, humane universal categories.

Keywords: initial capital, education, stagnation, economic crisis, effective manager, socially responsible business, patronage, role of individual in history

СТРОГАНОВ Алексей Валерьевич - аспирант кафедры истории и регионоведения Московского гуманитарного университета (111395, Россия, г. Москва, ул. Юности, 5; stroganovalexеy@yahoо. com)

\title{
ФЕНОМЕН ЖЕНСКОГО ПРОТЕСТА НА СЕЛЕ В МОСКОВСКОЙ ОБЛАСТИ В ПЕРИОД КОЛЛЕКТИВИЗАЦИИ
}

\begin{abstract}
Аннотация. В статье представлена интерпретация женского протеста на селе в период коллективизации, так называемых бабьих бунтов. Автор предпринимает попытку объяснить причины возникновения данного феномена, а также проанализировать поведенческие и мотивационные особенности сельских женщин на фоне происходящих событий, связанных с коллективизацией. Автор рассматривает закономерность, заключающуюся в частом доминировании женского протеста над мужским. Основой документального материала послужили архивные источники Рязанского и Калужского округов Московской области.
\end{abstract}

Ключевые слова: крестьянство, коллективизация, колхозы, протест, хлебозаготовки, раскулачивание

$\mathrm{H}$ а рубеже 1920-1930-х гг. в условиях коллективизации в СССР стихийно возникло явление женского протеста, именуемого «бабьими бунтами». Данный феномен своими корнями уходит в начавшиеся еще со второй половины XIX в. структурные изменения в жизни российской деревни. С того времени огромная часть крестьян, особенно из нечерноземных районов страны, начали регулярно уходить из своих деревень в город на заработки - так называемое отходничество. Женщины последовали примеру мужчин и массово стали устраиваться в городе кухарками, горничными, сиделками, прачками - иными словами, разного рода прислугой. Вся эта крестьянская масса перенимала бытовые привычки горожан, которые были гораздо более радикальными, чем у крестьян, заменяя, таким образом, свою патриархальную ментальность, основанную на господстве и подчинении младших членов семьи - старшим, жен - мужьям, детей - родителям, на возникающие образы новых современных мужчин и женщин. В деревне формировался новый менталитет крестьянина собственника, хозяина, который своим трудом кормит не только свою семью, но и всю не участвующую в процессе сельского производства страну, главным образом рабочих с промышленных предприятий.

Проблематика темы актуальна в связи с изучением роли женщин в различных сферах жизнедеятельности в период советской истории. Особое значение имел фактор связи женского менталитета с традициями родного края, малой родины, своего народа [Васильев 2018: 47-48, 64]. Игнорирование данного фактора могло иметь негативные последствия, в т.ч. политические [Васильев, Шепелев 2016: 12].

К периоду начала советской коллективизации ситуация в деревне была нака- 
лена из-за хлебозаготовок, которые с каждым годом становились все более обременительными и ожесточенными из-за постоянно увеличивающихся норм сдачи хлеба государству, которое забирало весь излишек не только у зажиточной части села, но и у основной деревенской прослойки - сельского середняка. В период массовой кампании создания колхозов и «добровольнопринудительного» записывания в них (этап появления так называемых бумажных колхозов) нередко на передний план протеста выступали женщины, о чем наглядно свидетельствуют архивные материалы ОГПУ: «Мы имеем такой случай, что женщины из деревни Желобовское Сараевского района подали заявление в партийную ячейку, пишут так, что мы в колхоз пока не хотим идти и в результате кончают: да здравствует советская власть, домой и до свидания колхозы» 1 .

Для женщины как для хранительницы домашнего очага и хозяйки, которая уже получила право голоса и умеет отстаивать свою точку зрения, но еще сохранила остатки традиционного русского менталитета, проявляющегося в осторожности, отсутствии склонности к риску, консерватизме и отрицании любых нововведений, особенно навязываемых сверху, немыслима сама идея обобществления частной собственности. Одновременно женщины поддерживали советскую власть, управлявшую страной. Представляется очевидным, что выступать открыто против власти для женщин было чрезвычайно опасно это повлекло бы за собой немедленный арест и различные формы репрессий. Сопротивление начиналось вокруг формирующихся колхозов. Типичная картина: когда собирались общие собрания, женщины массово садились вперед, оставляя мужчин сзади, и как только дело касалось организации колхозов, они устраивали шум и скандалы, нередко срывая таким образом собрания.

Архивные материалы свидетельствуют, что в течение первых двух зимних месяцев 1930 г. по мере стремительного роста процента коллективизированных хозяйств на селе активность женщин резко увеличивается. Это объясняется тем, что сельские активы вновь образованных колхозов начинали проводить обобществление семенных фондов (ссыпку семенного зерна в обобществленные амбары), а также обобществление рабочего скота (лошадей) и, самое главное, продуктивного скота (овец, свиней и коров). В ответ крестьяне массово резали свой скот, а в случае возникновения возможности - продавали его. Так поступил, например, отец моего деда, продав в последний момент двух лошадей из трех имевшихся, а одну отдал в колхоз [Щевьев 2018]. В других же случаях происходили открытые столкновения женщин с представителями власти по данному поводу. Об этом можно судить на основе почто-телеграммы, поступившей в Рязанский окружной отдел ОГПУ: «В слободах Казачья и Черная Шацкого района, во время работ бригадиров по обобществлению семенного материала 19 февраля с.г. в 9 часов утра собрались толпы женщин - до 300 человек в каждой слободе, и с криками "бей коммунистов, в колхоз не пойдем, вы нас грабите" - прогнали бригадиров. Прибывших в эти слободы конных милиционеров - обе толпы взяли в колья и прогнали» 2 .

Женщины более решительно, чем мужчины, проявляли готовность при помощи силы защищать нажитое годами, потом и мозолями имущество. Представители власти на местах объясняли подобные факты, с одной стороны, подрывной деятельностью и агитацией кулаков и попов, с другой - отсталостью женских масс в деревне. Также они признавали слабость и неграмотность

\footnotetext{
1 Центральный государственный архив города Москвы. Ф. ІІ-634. Оп. 1. Л. 268.

2 Рязанская деревня в 1929-1930 годах. Хроника головокружения: документы и материалы. М.: РОССПЭН. 1998. С. 254.
} 
в вопросах организации политической работы районных и сельских ячеек ВКП(б), а также то, что «комсомол гораздо более авторитетен в промышленных предприятиях, чем в колхозах» ${ }^{1}$.

Чтобы подчеркнуть значимость «бабьих бунтов» в общем течении протеста рязанского крестьянства против коллективизации, достаточно отметить повсеместное и массовое участие женщин в Пителинском (Веряевском) крестьянском восстании, прогремевшем на территории Рязанского округа в феврале 1930 г., которое охватило более десяти сел. Большая толпа женщин встретила направленный на подавление восстания в село Веряево сводный отряд из железнодорожной охраны и милиции. В результате возникшего противостояния отряд был вынужден покинуть село, не выполнив поставленную перед ним задачу.

Следует отметить, что женский протест на селе был обусловлен комплексом факторов. Одновременно с процессом коллективизации происходило массовое закрытие церквей и монастырей с разрушением и конфискацией их инвентаря и передачей освобождающихся площадей под хозяйственные нужды колхозов, а также массовые аресты и раскулачивание священнослужителей. Женщины, составлявшие основную массу прихожан, решительно и повсеместно вступали в противоборство с антицерковной политикой районных и сельских исполнительных комитетов. Приведем следующий пример: «5 февраля вечером бригадиры по коллективизации явились к попу села Картоносова и Деулина описывать имущество перед раскулачиванием. Поп в это время был на крестинах и, узнав о приходе бригадиров, сказал окружающим, что его пришли арестовывать. Бабкаповитуха и церковная сторожиха собрали толпу женщин человек 300, которая окружила бригадиров, крича “Бей их”. Никакие уговоры не действовали, и только прямая угроза оружием заставила женщин разойтись и спасла бригадиров от избиения» 2 . В данном случае можно отметить коварное поведение попа, который простым манипулированием женщинами добился возникновения массовых беспорядков на селе и сорвал, пусть и временно, замысел бригадиров.

Помимо выступлений против разорения церквей и раскулачивания священнослужителей, женщины часто вступались за раскулаченных односельчан: «22 апреля 1930 года, в 4 часа вечера в с. Сербино, Ухоловского района, толпа женщин - около 100 человек, пришла в организованный колхоз, потребовав от последнего скот, изъятый от кулацких хозяйств при раскулачивании. Затем самолично взяли двух коров и отвели раскулаченным Орлову и Казакову» 3 . На основе данного случая можно предположить, что женщины гораздо более активно, чем мужчины, реагировали на несправедливость, происходящую по отношению к другим людям. Коллективное чувство жалости и сострадания на фоне сильной эмоциональности и быстрой самоорганизации очень часто позволяли женщинам разрушать замыслы местной исполнительной власти.

После публикации 2 марта 1930 г. в газете «Правда» статьи И.В. Сталина «Головокружение от успехов» в течение последующих двух месяцев число коллективизированных дворов в Рязанской губернии сократилось с $75 \%$ до $8 \%$. Краткосрочное возвращение крестьян к единоличному хозяйствованию дало еще один повод для женских протестов. Началась борьба основной массы крестьянства с отводами лучших земель колхозам: «16 марта на землях, принадлежащих гражданам деревень Панской, Большой и Малой Пановки и Сосновки,

1 Российский государственный архив социально-политической истории (РГАСПИ). Ф. М-1. Оп. 3. Д. 64. Л. 288.

2 Рязанская деревня в 1929-1930 годах. Хроника головокружения: документы и материалы. М.: РОССПЭН. 1998. С. 339.

3 Государственный архив Рязанской области. Ф. Р-5. Оп. 1. Д. 223. Л. 363. 
происходило землеустройство для перехода с 3-польного на 4-польный севооборот. План землеустроения был предварительно разработан и обсужден на собрании бедноты и пленуме Соловьяновского с/совета. Землеустроителю были даны рабочие из выше указанных деревень. Когда уже поставили столбы, подошло 40 женщин и стали прогонять землеустроителя и рабочих, вытаскивать столбы, жечь и разбирать их, а также “трепать” уполномоченного деревни Сосновки Драгункина» 1 .

Одновременно с борьбой за возвращение земельных наделов женщины вступали в борьбу за возвращение при выходе из колхоза коллективизированных ранее рабочего инвентаря, а также рабочего и продуктивного скота и семенных фондов. Следует отметить, что иногда эта борьба принимала комические оттенки: «Репетиция посылки ходоков к товарищу Калинину... В деревне Васисово, Якушевского сельсовета, женщины при выходе из колхоза написали заявление на имя т. Калинина, избрали из своей среды ходока Екатерину Дулову и женщину, которая должна была играть роль товарища Калинина гражданку Лобиненкову. Последнюю посадили на стул, и к ней в присутствии всех женщин подходила гражданка Дулова и говорила: “Дорогой Михаил Иванович, мы целыми годами наживали коров и лошадок, а теперь их у нас отбирают в колхоз, отмените это дело, нам очень жаль с ними расставаться”. Женщины в это время кричали: “Уж очень ты, Катерина, говоришь хорошо”» 2 . Приведенный факт свидетельствует о том, что поведение женщин далеко не всегда рационально по своей сути, массовая протестная энергия превращалась фактически в организацию театральной постановки, за которой с внутренним удовлетворением наблюдали колхозные активисты. Даже через скупые строки приведенного документа заметно, как женщины, проявляя свою активность и осознавая высокую ее важность для их деревенского сообщества, не понимали, что по сути вся их деятельность проходит вхолостую.

Представляется очевидным, что руководящие органы ВКП(б) хорошо осознавали мощный потенциал женских крестьянских масс советской деревни. Органы власти постоянно предпринимали попытки привлечения этой силы на свою сторону. Для этого проводились самые разные мероприятия, которые широко освещались в советской печати: «За последние годы работы делегатские собрания крестьянок в общественной жизни деревни играли значительную роль, способствуя практическим успехам мероприятий партии и советской власти в деревне, мобилизуя внимание широких трудящихся женских масс вокруг хлебозаготовок, займа индустриализации, самообложения и т.д. Актив делегаток является опорой низовых организаций в их повседневной работе. Делегатки выдвигаются в руководящие низовые организации деревни. Сейчас, когда мы вступили в полосу строительства крупного социалистического земледелия, значимость женских масс в сельском хозяйстве еще увеличивается. Женские массы представляют огромный резерв творческой силы, и задачей делегатских собраний вместе со всей партией - помочь тысячам беднячек и середнячек осознать необходимость борьбы за коллективизацию. Вопрос этот приобретает особую остроту в связи с обострившейся классовой борьбой, когда враги рабочего класса, кулаки и попы, стараются использовать в своих интересах наиболее отсталые женские массы деревни» ${ }^{3}$. Роль женщины в колхозном строительстве обсуждалась на пленуме ЦК ВЛКСМ, где подчеркива-

\footnotetext{
1 Рязанская деревня в 1929-1930 годах. Хроника головокружения: документы и материалы. М.: РОССПЭН. 1998. С. 495.

2 Государственный архив Калужской области. Р-202. Оп. 1. Д. 7. Л. 38.

3 Беднота. 1929. 13 декабря.
} 
лась «чрезмерно слабая работа среди девушек» ${ }^{1}$. Отмечалась необходимость «самого широкого развития всех форм массовой работы среди девушек, созыв конференции и собраний девушек, в частности девушек-колхозниц; развить культурно-бытовую работу среди них и, проводя различную массовую работу среди девушек, необходимо усилить рост деревенских организаций Союза за счет их» ${ }^{2}$. Данная оценка в целом объясняет неудачу попытки перетянуть значительное число женщин на поддержку коллективизации. На самых верхних этажах партийной иерархии звучали шаблонные заявления по поводу участия женщин в колхозном строительстве, однако они не имели практической реализации и не претворялись в жизнь. К тому же в самые жаркие месяцы коллективизации местным органам власти было не до «развития культурно-бытовой работы» среди девушек.

В результате значительная часть крестьянского женского населения страны оказалась в оппозиции к политике коллективизации сельского хозяйства. В этой связи следует отметить особенность женского менталитета, отмеченную еще в дореволюционные времена известным в XIX в. публицистом-народником Александром Николаевичем Энгельгардтом: «Все, говорят, от баб, все дележки от баб, весь бунт от баб: бабы теперь в деревне сильны. Действительно, сколько и я мог заметить, у баб индивидуализм развит еще более, чем у мужиков, бабы еще эгоистичнее, еще менее способны к общему делу - если это дело не общая ругань против кого-либо, - менее гуманны, более бессердечны. Мужик, в особенности если он вне дома, вне влияния баб, еще может делать что-нибудь сообща; он не так считается в общей работе, менее эгоистичен, более способен радеть к общей пользе двора, артели, мира, жить сообща, а главное - мужик не дребезжит, не разводит звяк, не точит. Мужик надеется на свой ум, на свою силу, способность к работе. Баба не надеется ни на ум, ни на силу, ни на способность к работе, баба все упование свое кладет на свою красоту, на свою женственность, и если раз ей удалось испытать свою красоту - конец тогда» [Энгельгардт 1999: 262].

Благодаря пониманию особенностей женской ментальности, в конечном итоге становятся более понятными те многочисленные женские выступления, которые охватили нашу страну на рубеже 1920-1930-х гг. и которые нуждаются на сегодняшний день в более глубоком исследовании представителями исторического сообщества современной России. Женщина нередко гораздо сильнее будет бороться за свою собственность, чем мужчина. Там, где дело касается ее собственности, часто именно женщина первой выходит на ее защиту, оставляя мужчин, являющихся более рациональными по своей природе, позади. Женщины меньше опасаются карательных действий со стороны властей за свои действия. Они более эмоционально неустойчивы, легче выпускают свой гнев, более жалостливы, всегда заступаются за незаслуженно обиженного земляка. Также следует признать, что они действительно значительно легче подвержены различным манипуляциям, таким как агитация со стороны уважаемых представителей деревенского сообщества (кулаки, священнослужители).

\section{Список литературы}

Васильев Ю.А. 2018. Юрий Андропов. На пути к власти. М.: Вече. 416 с.

Васильев Ю.А., Шепелев В.Н. 2016. Борьба политических элит в условиях позднего сталинизма. Карельский отголосок «Ленинградского дела». 19491950 гг. - Исторический архив. № 3. С. 3-31.

\footnotetext{
1 РГАСПИ. Ф. М-1. ОП. 3. Д. 67. Л. 92.

2 Там же.
} 
Щевьев И. И. 2018. Молодость Ивана. Беседы с дедом (сост. А.В. Строганов). М.: Книга-Мемуар. 178 с.

Энгельгардт А. Н. 1999. Из деревни. 12 писем 1872-1887. СПб: Наука. 725 с.

STROGANOV Aleksei Valer'evich, postgraduate student at the Chair of History and Regional Studies, Moscow University for the Humanities (5 Yunosti St, Moscow, Russia, 111395; stroganovalexey@yahoo.com)

\title{
THE PHENOMENON OF WOMEN'S PROTEST IN RURAL AREAS IN THE MOSCOW REGION DURING COLLECTIVIZATION
}

\begin{abstract}
The article presents an interpretation of women's protest in rural areas during the period of collectivization, the so-called "women's riots". The author attempts to explain the causes of this phenomenon, as well as to analyze the behavioral and motivational characteristics of rural women, against the background of events occurring and related to collectivization. The author considers the pattern, which consists in the frequent dominance of female protest over the male one. The documentary material is based on archival sources of the Ryazan and Kaluga districts of the Moscow Region. Keywords: peasantry, collectivization, collective farms, protest, grain procurement, dispossession
\end{abstract}

ЦЕЛОВАЛЬНИКОВА Ирина Ивановна - кандидат исторических наук, доцент кафедры истории Ульяновского государственного педагогического университета им. И.Н. Ульянова (432071, Россия, г. Ульяновск, пл. Ленина, 4/5, celo-iri@yandex.ru)

\section{УЧАСТИЕ СЕЛЬСКОХОЗЯЙСТВЕННЫХ КООПЕРАТИВОВ В РОССИИ \\ В ОРГАНИЗАЦИИ ПОСТАВОК ДЛЯ АРМИИ В ГОДЫ ПЕРВОЙ МИРОВОЙ ВОЙНЫ (на примере Среднего Поволжья)}

Аннотация. В статье рассматривается участие сельскохозяйственных кооперативных организаций в поставках продовольствия и изделий кустарного промысла для армии в годы Первой мировой войны. Автор анализирует причины неудач первых кампаний хлебных поставок кооперативов, а также мероприятия по их преодолению и приходит к выводу, что участие кредитных товариществ в поставках зерна и хлеба для армии способствовало развитию производственной кооперации, появлению трудовых артелей, которые также работали на военное ведомство. Отдельное внимание автор уделяет сложным отношениям кооперативов с уполномоченными по закупкам и земством.

Ключевые слова: сельскохозяйственная кооперация, военные поставки, Первая мировая война, сельское хозяйство, Среднее Поволжье

B условиях военного времени происходит значительная перестройка экономической системы страны под нужды армии. От успешности этой трансформации, эффективности созданной системы снабжения во многом зависит успешность действий армии. В России в годы Первой мировой войны одним 